\title{
Dampak Aktivitas Penambangan Pasir Dan Batu Terhadap Kelestarian Geopark di Kaldera Gunung Batur, Kecamatan Kintamani, Kabupaten Bangli
}

\author{
I Kadek Alit Wiguna, I Gede Budiarta, I Putu Ananda Citra \\ Prodi Pendidikan Geografi \\ Universitas Pendidikan Ganesha \\ Singaraja, Indonesia
}

e-mail:\{alitwiguna1@gmail.com, budiartagd geo@yahoo.co.id, anandageo07@yahoo.com\}

\begin{abstract}
Abstrak
Penelitian ini dilaksanakan di Kecamatan Kintamani dengan tujuan yaitu: (1) Mendeskripsikan karakteristik aktivitas penambangan pasir dan batu di Kaldera Gunung Batur; (2) Mendeskripsikan pengelolaan aktivitas penambangan pasir dan batu di Kaldera Gunung Batur; (3) Menganalisis dampak aktivitas penambangan pasir dan batu terhadap kelestarian Geopark di Kaldera Gunung Batur. Rancangan penelitian yang digunakan adalah deskriptif, yang menjadi populasi yaitu masyarakat yang bekerja di tambang pasir dan batu sebanyak 336 orang, dengan jumlah sampel 41 Orang. Metode pengumpulan data yang digunakan adalah metode observasi, wawancara, dan kuesioner. Metode analisis data yang digunakan yaitu deskriptif kualitatif. Hasil penelitian menunjukan bahwa (1) karakteristik penambangan pasir dan batu di Kaldera Gunung Batur tergolong intensif dilakukan, ini dilihat dari intensitas penambangan yang tinggi yaitu 70,73\% dimana penambang melakukan kegiatan penambangan hampir setiap hari, pengunaan kedua alat modern dan tradisional $56,10 \%$, lokasi milik sendiri $77,78 \%$ dan sisanya menyewa, dan pekerja yang bekerja murni masyarakat setempat. (2) Pengelolaan penambangan pasir dan batu di Kaldera Gunung Batur dilakukan secara berkelompok menggunakan teknik penambangan terbuka dengan penggunaan alat modern dan tradisional dengan harga jual dikisaran $\mathrm{Rp}$. 400.000. (3) Dampak aktivitas penambangan pasir dan batu di Kaldera Gunung Batur banyaknya lubang-lubang bekas tambang yang belum dilakukan penimbunan, rusaknya jalan akibat dari truk pengangkut pasir dan batu, terganggunya kelangsungan hidup flora dan fauna dan memberi peluang kerja masyarakat sekitar lebih luas, sedangakan kelestarian geopark masih dapat dikatakan lestari karena aktivitas penambang diluar kawasan konservasi/lindung.
\end{abstract}

Kata kunci: penambangan pasir dan batu, kelestarian, geopark.

\footnotetext{
Abstract

This research was conducted in Kintamani Sub-district with the aim of: (1) Describing characteristic of sand and stone mining activity at Gunung Batur caldera; (2) Describing the management of sand and stone mining in Gunung Batur caldera; (3) To analyze the impact of sand and stone mining on Geopark preservation in Gunung Batur caldera. The research design used is descriptive, the population is the people who work in sand and stone mines as much as 336 people, with the number of samples 41 Orang. Method of data settlement used is observation method, interview, and questionnaire. Data analysis method used is descriptive qualitative. The results showed that (1) sand and stone mining characteristic in Gunung Batur Caldera was classified intensively, it was seen from the high mining intensity that is $70,73 \%$ where
} 
the miner do mining activity almost everyday, the use of both modern and traditional tools $56,10 \%$, Own Locations $77.78 \%$ and. (2) The management of sand and stone mining in Gunung Batur caldera is done in groups using open pit mining techniques with the use of modern and traditional tools with selling price of Rp. 400,000. (3) Sand and rock mining activities at Gunung Batur Caldera many unlogged mining holes, road damage caused by sand and rock transport trucks, disruption of flora and fauna survival and provide wider community employment opportunities, while Sustainability Geopark can still be said to be sustainable due to mining activities in protected areas.

Keywords: Sand stone mining, sustainability, geopark.

\section{PENDAHULUAN}

Geopark Batur merupakan situs warisan dunia yang terjadi akibat proses erupsi atau meletusnya Gunung Batur. Erupsi atau meletus Gunung batur ini di karenakan Gunung Batur merupakan gunung api yang aktif, sudah tidak asing lagi kalau mendengar banyak terjadi erupsi gunung api khususnya di Indonesia. Indonesia merupakan wilayah yang terdapat lingkaran api pasifik, sehingga bencana alam seperti gempa bumi dan erupsinya gunung sering terjadi.

Gunung meletus atau erupsi gunung identik dengan terjadinya kerusakan/bencana alam, namun di lain sisi menjadi sebuah berkah. Hal tersebut dapat dilihat dari setelah selesainya bencana alam gunung yang erupsi. Gunung yang erupsi akan menghasilkan abu vulkanik. Permukaan tanah yang terkena abu vulkanik akan menyebabkan permukaan tanah atau top soil menjadi subur, sehingga tanaman yang di tanam akan menjadi lebih baik dari sebelumnya. Indonesia yang kaya akan gunung berapi membuat wilayah Indonesia rentan atau berisiko akan terjadinya gunung yang erupsi. Salah satu gunung berapi yang ada di Indonesia terletak di pulau Bali khususnya di Kintamani Bangli yang bernama Gunung Batur. Gunung Batur sudah mengalami letusan berulang kali. Seperti berita yang tersebar media masa maupun di kalangan masyarakat bahwa Gunung batur tersebut sudah mengalami letusan atau erupsi sebanyak 26 kali, yaitu dari tahun 1804 sampai tahun 2000. Tepatnya Tanggal 2 Agustus sampai 21 September 1926 merupakan letusan atau erupsi yang paling dahsyat dari keseluruhan letusan Gunung Batur.

Keseluruhan erupsi Gunung Batur telah menghasilkan banyak mineral pasir, batu, dan kawah/danau yang sekarang dimanfaatkan oleh masyarakat sekitar untuk menunjang kehidupannya ataupun perekonomiannya. Hal tersebut dapat di lihat dari pekerjaan masyarakat sekitar ada yang memelihara ikan di danau batur atau sering disebut dengan tambak ikan. Selain itu juga ada pekerjaan masyarakat sebagai penggali pasir dan batu. Hal tersebut bukan terjadi tanpa sebab, melainkan dari adanya berkah akibat Gunung Batur yang erupsi pada waktu puluh tahun sebelumnya.

Awal terjadinya penggalian pasir yang terdapat di Gunung Batur, yaitu bermula dari dibukanya lahan galian $\mathrm{C}$ yang dipelopori oleh Bapak Jero Pugeg pada tahun 1990. Dengan di bukanya lahan galian $\mathrm{C}$ membuka ruang masyarakat sekitar untuk mendapat mata pencarian baru sebagai penambang pasir. Galain C milik Bapak Jero Pugeg menjadi awal perkembangan usaha pertambangan pasir di Desa Songan, Kecamatan Kintamani, Kabupaten Bangli. Tahuntahun berikutnya, usaha penggalian pasir semakin meningkat dikarenakan usaha penggalian pasir dianggap mampu meningkatkan taraf hidup masyarakat Desa Songan.

Aktivitas

penambangan menyebabkan perubahan bentang lahan serta berubahnya kualitas tanah. Akibat adanya hal tersebut struktur penutup tanah menjadi rusak karena tanah bagian atas (top soil) digantikan dengan tanah lapisan bawah yang kurang subur. 
Demikian juga populasi hayati tanah yang ada di tanah lapisan atas menjadi terbenam, sehingga menjadi hilang atau mati dan tidak berfungsi sebagaimana mestinya. Akibatnya daya dukung tanah lapisan atas pasca penambangan untuk pertumbuhan tanaman menjadi rendah (Subowo, 2011).

Segala aktivitas yang berkaitan dengan pemanfaatan sumber daya alam akan menimbulkan dampak, baik dampak positif maupun negatif. Pemanfaatan sumber daya alam kini telah menimbulkan dampak negatif bagi lingkungan. Ketika manusia mengeksploitasi sumber daya alam secara berlebihan, maka fungsi lingkungan serta kelestarian sumber daya alam akan mengalami penurunan (Kartodihardjo, 2005). Salah satu aktivitas pemanfaatan sumber daya alam yang memberikan dampak negatif adalah penambangan batu pasir. Aktivitas penambangan tersebut akan menimbulkan dampak negatif terhadap lingkungan di sekitar Kaldera Gunung Batur. Masyarakat umumnya tidak memperdulikan dampak dari aktivitas penambangan yang mereka lakukan, karena mereka hanya peduli dengan keuntungan yang didapat dari hasil penambangan tersebut.

Tanah yang terletak pada kawasan penambangan menjadi lahan yang tidak produktif, itu karena lahan yang telah dikerjakan oleh pertambangan sebagian besar tidak direklamasi (Nurdin dkk, 2000). Dengan tidak direklamasi atau diurug tanah tersebut sehingga permukaan tanah tidak seperti pada awalnya. Hal tersebut mengakibatkan berbagai perubahan lingkungan, antara lain perubahan bentang alam, perubahan habitat flora dan fauna, perubahan struktur tanah, dan perubahan pola aliran air permukaan serta perubahan aliran air tanah. Perubahan-perubahan tersebut menimbulkan dampak dengan intensitas dan sifat yang bervariasi (Dyahwanti, 2007).

\begin{tabular}{llr}
\multicolumn{2}{c}{ Kawasan Gunung } & Batur \\
merupakan kawasan objek & $\begin{array}{r}\text { wisata } \\
\text { sekaligus }\end{array}$ kawasan & kegiatan
\end{tabular}

penambangan. Hal tersebut dapat dilihat dari aktivitas yang dilakukan masyarakat, baik dari segi wisatawan yang berkunjung kesana dan kegiatan yang dilakukan masyarakat di Kaldera Batur atau yang sekarang menjadi kaki dari Gunung Batur. Kedua aktivitas tersebut sangat bersebrangan, dimana kawasan Gunung Batur sendiri ditetapkan oleh pemerintah daerah dan pusat sebagai Kawasan Geopark. Dengan berbagai upaya yang dilakukan oleh berbagai pihak yang membidangi hal tersebut sehingga berhasil dipercaya oleh UNESCO sebagai salah satu jaringan taman bumi dunia (Geopark Global Network).

Kegiatan masyarakat yang ada di kawasan Gunung Batur terutama yang bermatapencarian sebagai penambang pasir dan batu sangat bersebrangan dengan penetapan batur sebagai Batur Geopark Internasional, sehingga hal tersebut menjadi keraguan beberapa masyarakat, dikarenakan kawasan yang semestinya harus di jaga kelestariannya, tetapi ada kegiatan penambangan galian C. Hal lain juga disampaikan oleh pelaku wisata, salah satu yang menyerukannya, yaitu Asosiasi Biro Perjalanan Wisata (ASITA) Bali, menyerukan kepada pemerintah Kabupaten Bangli untuk mencabut izin usaha penambangan galian golongan $\mathrm{C}$ berupa batu pasir di Kawasan Kawah Gunungapi atau Kaldera Gunung Batur, Kintamani, Bangli. Seruan tersebut disampaikan mengingat bahwa Kawasan Kaldera Batur telah ditetapkan sebagai bagian dari Global Geopark Network (GGN) atau Jaringan Taman Bumi Dunia oleh UNESCO pada 20 September 2012 (Voaindonesia).

Dampak parah yang terlihat dari adanya aktivitas penambangan bahan pasir dan batu adalah matinya ataupun rusaknya tumbuhan yang semestinya hidup di atas lahan tambang, seperti yang telihat pada Gambar 1.2. Hal tersebut dikarenakan kegiatan penambangan dilakukan penggalian-penggalian dan tidak memikirkan dampak sekitarnya.

Melihat besarnya dampak kerusakan lingkungan fisik yang disebabkan oleh adanya aktivitas penambangan pasir dan batu di Kaldera Geopark Batur perlu adanya penelitian tentang dampak aktivitas penambangan terhadap lingkungan fisik. Sehingga dengan 
mengetahui dampak yang ditimbulkan, masyarakat serta pemerintah Kabupaten Bangli diharapkan dapat bekerjasama dalam melestarikan, menjaga dan mencegah terjadinya kerusakan lingkungan fisik yang lebih parah di Kawasan Geopark Batur.

Besarnya fungsi pasir dan batu untuk kegiatan pembangunan fisik membuat masyarakat kurang kepedulian terhadap dampak negatif yang ditimbulkan dari aktivitas penambangan batu pasir di kawasan Geopark Batur. Oleh karena itu, diperlukan usaha untuk memperbaiki kondisi lingkungan di Geopark Batur tersebut, sehingga Kawasan Geopark Batur dapat dimanfaatkan dengan baik oleh masyarakat.

Terdapatnya kendala yang ada di Kaldera Gunung Batur menimbulkan berbagai permasalahan, mengingat kawasan tersebut merupakan kawasan yang sudah seharusnya dijaga. Dengan adanya hal tersebut sudah seharusnya kawasan tersebut dilertarikan, mengingat kawasan tersebut merupakan kawasan wisata, jejak sejarah terbentuknya Kawasan Kintamani dan sekitarnya, dan sekaligus yang dilindungi oleh pemerintah sebagai sistus penting ilmiah sebagai sumber pengembangan ilmu pengetahuan.

Tujuan dari penelitian ini adalah Mendeskripsikan karakteristik aktivitas penambangan pasir dan batu, mendeskripsikan perkembangan pengelolaan aktivitas penambangan pasir dan batu, dan menganalisis dampak aktivitas penambangan pasir dan batu terhadap kelestarian Geopark di Kaldera Gunung Batur, Kecamatan Kintamani, Kabupaten Bangli.

\section{METODE PENELITIAN}

Penelitian ini adalah penelitian deskriptif dengan analisis kualitatif. Rancangan deskriptif digunakan untuk mendeskripsikan (1) karakteristik aktivitas penambangan pasir dan batu, (2) perkembangan pengelolaan aktivitas penambangan pasir dan batu, dan (3) dampak aktivitas penambangan pasir dan batu terhadap kelestarian Geopark.
Lokasi yang digunakan oleh peneliti dalam penelitian ini adalah Kaldera Geopark Batur, yang secara administratif berada di Kecamatan Kintamani, Kabupaten Bangli. Alasan pemilihan lokasi ini karena Kaldera Geopark Batur memendam banyak mineral dari hasil erupsi Gunung Batur pada beberapa dekade yang lalu. Salah satu mineral tersebut yaitu berupa mineral golongan $\mathrm{C}$ (pasir dan batu). Dengan adanya pasir dan batu di kawasan Kaldera Gunung Batur membuat minat masyarakat sekitar untuk melakukan kegiatan bermatapencaharian sebagai penambang pasir dan batu.

Objek penelitian ini adalah aktivitas penambangan pasir dan batu. Sedangkan subjek dalam penelitian ini adalah masyarakat yang bekerja di penambangan pasir dan batu atau pelaku penambangan pasir dan batu di Kaldera Gunung Batur, Kecamatan Kintamani, Kabupaten Bangli. Populasi di dalam penelitian ini adalah masyarakat yang bekerja sebagai penambang pasir dan batu di lokasi penelitian. Berdasarkan hasil wawancara pada hari Rabu, 27 Desember 2016 dengan salah satu pengelola tambang dan pekerja tambang, jumlah pekerja yang bermatapencarian sebagai penambang pasir dan batu berjumlah 336 orang. Pekerja tambang berasal dari masyarakat lokal di Kaldera Gunung Batur, yaitu Desa Batur Utara, Desa Batur Selatan, Desa Batur Tengah, Desa Songan A dan Desa Songan B. Jumlah populasi yang besar dengan waktu dan biaya yang terbatas, maka tidak seluruh populasi dapat diteliti. Untuk itu akan dilakukan pengambilan sampel dengan teknik purposive sampling. Purposive sampling adalah teknik yang digunakan apabila anggota sampel yang dipilih secara khusus berdasarkan tujuan penelitian (Usman dan Akbar, 2011). Alasan menggunakan penambang untuk dijadikan sampel karena penambang sebagai subjek dalam penelitian ini. Mengacu pada ketentuan Arikunto (1992), yang menyatakan bahwa apabila subjeknya lebih dari 100, maka subjek yang dapat di ambil antara $10 \%-15 \%$ atau lebih, yaitu sebagai syarat untuk menentukan analisis. Berdasarkan 
ketentuan tersebut, maka sampel yang diambil dalam penelitian ini sebesar $12 \%$, sehingga sampel yang di ambil menjadi 40,32 dibulatkan menjadi 41 orang.

Teknik pengumpulan data yaitu menggunakan metode survei dengan instruman berupa kuesioner. Kemudian dilakukan pengolahan data dan dianalisis agar memperoleh suatu kesimpulan sebagai hasil penelitian. Metode analisis data yang digunakan yaitu analisis kualitatif.

\section{HASIL DAN PEMBAHASAN \\ Karakteristik Aktivitas Penambangan Pasir dan batu di Kaldera Gunung Batur}

Secara teoritis dalam karakteristik kegiatan panambangan pasir dan batu merupakan kegiatan industri. Industri ekstraktif adalah suatu kegiatan untuk mendapatkan barang yang dibutuhkan yang terdapat di dalam atau di permukaan bumi maupun di bawah permukaan air laut yang akan digunakan untuk berbagai kegiatan industri lainnya. Sukandarrumidi (1997), secara umum menjelaskan karakteristik kegiatan penambangan yang baik meliputi: penyelidikan umum, eksplorasi, eksploitasi, pengolahan dan pemurnian, pengangkutan, dan pemasaran. Penyelidikan umum, eksplorasi, dan pemasaran belum menimbulkan gangguan keseimbangan lingkungan hidup yang berarti, tetapi eksploitasi, pengolahan/pemurnian, dan pengangkutan dapat mengakibatkan gangguan keseimbangan lingkungan hidup yang cukup besar (Katili, 1983).

Berdasarkan hasil penelitian,

penambangan pasir dan batu di Kecamatan Kintamani ada beberapa indikator yang dijadikan tolak ukur yaitu:
a). Intensitas Penambangan,
b). Perlengkapan Alat yang Digunakan,
c). Kepemilikan lokasi Penggalian,
d). Alat angkut yang digunakan, dan
e). Daerah Asal.

Karakteristik

kegiatan

penambangan Pasir dan batu di Kecamatan Kintamani memiliki ciri khas yang berbeda dibandingkan daerah lain. Dimana penambangan pasir dan batu dilakukan di Kaldera Gunung Batur. Dari kegiatan penambangan tersebut dapat dilihat dari dua sisi, yaitu positif dan negatif. Sisi positif dari kegiatan penambangan yang dilakukan di Kecamatan Kintamani pekerja tambang berasal dari daerah setempat. Sedangkan sisi negatif dari kegiatan penambangan yang dilakukan menggunakan alat modern. Penggunaan alat modern tersebut tentunya akan lebih mudah mengeksploitasi mineral pasir dan batu yang lebih banyak lagi. Pengeksploitasian yang lebih banyak tentunya akan mengancam kelestarian lingkungan itu sendiri.

\begin{tabular}{lll}
\multicolumn{3}{c}{ Kegiatan penambangan pasir dan } \\
batu di & Kecamatan & Kintaman \\
menunjukkan & bahwa & intensitas \\
penambangan pasir dan & batu di
\end{tabular}
Kecamatan Kintamani yang tersebar pada Kaldera Gunung Batur tergolong Tinggi. $\mathrm{Hal}$ itu mengacu pada hasil kuesioner yang disebar ke panambang. Hasil penyebaran kuesioner terkait intensitas penambangan mendapat hasil 70,73\% penambang bekerja setiap harinya. Intensitas yang tinggi tersebut terjadi karena mata pencaharian pokoknya yaitu sebagai penambang pasir dan batu. Hasil penuturan Bapak Oka selaku pekerja tambang pasir dan batu mengatakan bahwa pekerja tambang biasanya bekerja mulai dari jam 5 pagi sampai jam 3 sore.

Pekerjaan penambangan pasir dan batu merupakan pekerjaan penggalian struktur lapisan tanah yang memiliki potensi terdapatnya mineral pasir dan batu di dalam tanah tersebut. Tentunya dalam penggalian pasir dan batu memerlukan alat, baik itu alat tradisional ataupun alat modern. Berdasarkan hasil yang di dapat saat penelitian di Kaldera Gunung Batur didapatkan alat-alat yang digunakan pekerja tambang untuk menggali pasir dan batu.

Hasil yang didapat di lapangan pekerja tambang menggunakan alat tradisional (sederhana) dan alat modern sebesar $56,10 \%$ dari 41 orang responden. Sedangkan, pekerja tambang yang hanya menggunakan alat tradisional sebesar $21,95 \%$ dan pekerja tambang yang hanya menggunakan alat modern sebesar $21,95 \%$. Penggunaan kedua alat 
tradisononal dan modern oleh pekerja tambang yaitu bertujuan untuk mempercepat pekerjaan dan memperoleh hasil yang lebih banyak.

Berdasarkan hasil survei yang dilakukan di lokasi penambangan, kepemilikan lokasi menunjukan bahwa $77,78 \%$ kepemilikan lokasi penggalian pasir dan batu itu merupakan lahan milik sendiri dan $22,22 \%$ lokasi penambangan tersebut milik orang lain atau menyewa. Hal tersebut berdasarkan hasil kuesioner yang diberikan kepada responden di lokasi penelitian di Kecamatan Kintamani. Milik sendiri yang dimaksudkan yaitu lokasi penambangan tersebut milik keluarga maupun kerabat-kerabat terdekat mereka (penambang). Mereka bersamasama mengelolah tambang tersebut sebagai mata pencarian utama maupun sampingan.

Masyarakat yang menyewakan lahan untuk dijadikan lokasi penambangan biasanya masyarakat yang tidak berkecimpung di penambangan pasir dan batu atau memiliki mata percaharian yang lain, sehingga lahannya tersebut disewakan. Hal ini didukung oleh hasil penelitian yang dilakukan oleh Nurul In (2015), menyatakan bahwa petani yang memiliki lahan pertanian di Desa Lenek Daya dan Desa Lenek Kali Bambang saat ini lebih banyak tertarik menyewakan lahan pertaniaannya untuk diambil pasir dan batunya, bahkan adapula yang menjual lahannya untuk dijadikan tempat penambangan pasir dan batu.

Daerah asal pekerja tambang merupakan faktor penting. Hal tersebut untuk mengetahui apakah yang memanfaatkan sumber daya alam sekitar adalah masyarakat lokal (setempat) atau masyarakat luar. Berdasarkan hasil yang didapatkan dari responden, masyarakat yang bekerja di penambangan pasir dan batu merupakan masyarakat lokal. Hal tersebut karena masyarakat di lokasi penambangan tidak memberikan izin masyarakat luar untuk bekerja di penambangan pasir. Tujuan tidak diberikan masyarakat luar untuk ikut bekerja di penambangan pasir karena dikhawatirkan mengurangi kesempatan bekerja masyarakat lokal.
Aktivitas penambangan di Kaldera Gunung Batur Kecamatan Kintamani hanya menghasilkan mineral pasir dan batu. Hasil kuesioner yang disebar ke responden menunjukan bahwa penambangan di lokasi penelitian hanya menambang pasir dan batu. Hal tersebut karena hanya pasir dan batu saja yang terdapat di lokasi penelitian. Kuesioner tersebut menjawab $100 \%$ responden mengatakan bahwa mereka menambang pasir dan batu secara bersamaan.

\section{Aktivitas Pengelolaan Penambangan Pasir dan batu di Kaldera Gunung Batur}

Aktivitas

pengelolaan

penambangan bahan pasir dan batu Kaldera Gunung Batur Kecamatan Kintamani dilakukan selama delapan hingga sepuluh jam. Biasanya penambang mulai bekerja pada pukul 05.00 WITA hingga pukul 15.00 WITA. Mereka umumnya menggunakan alat modern dan tradisional yang berupa berupa exvalator, linggis, skop dan jaring, untuk menggali pasir dan batu di lokasi tambang. Penggunaan exavalator yaitu digunakan untuk pengkerukan pasir dan batu. Tentunya dengan adanya alat modern akan mempercepat pengkerukan dan memudahkan penambang melakukan pekerjaannya. sedangkan penggunaan alat tradisional yaitu skop dan jaring digunakan sebagai pemilah pasir dengan butiran yang besar dengan pasir yang kecil.

Adapun beberapa indikator yang dijadikan acuan untuk menjawab rumusan masalah kedua, yaitu: jumlah bahan tambang, teknik penambangan, nilai ekonomis, pemasaran pasir dan batu.

Dalam penambangan tentunya akan mendapankan jumlah bahan tambang. Berdasarkan hasil kuesioner penambangan pasir dan batu di Kaldera Gunung Batur rata-rata yang paling banyak mendapatkan pasir dan batu sejumlah 1,5 truk per hari untuk satu orang pekerja. Lain halnya jika kondisi penambang kurang baik maka jumlah yang di tambang hanya mencapai 1 truk bahkan bisa kurang, namun juga ada waktu dimana penambang bisa 
mendapatkan pasir dan batu sampai 2 truk per orang. Pekerja tambang yang mendapat pasir maupun batu hingga 2 truk biasanya bahan tambang yang di gali tekstur lahannya lebih gembur disertai dengan cuaca yang mendukung.

Pekerja tambang menggali pasir dan batu menggunakan teknik penambangan terbuka. Penambangan dengan teknik terbuka ini dilakukan terlebih dahulu menghilangkan vegetasi/pohon-pohon kecil di atas lokasi yang akan dijadikan lokasi tambang. Penebangan tersebut dilakukan karena pasir maupun batu yang di tambang berada di bawah vegetasi tersebut. Jika penambang kehabisan bahan tambang (pasir dan batu), maka para penambang akan membuka lokasi / lahan baru. Pembukaan lahan baru tentu terlebih dahulu menghilangkan vegetasi di atas lokasi yang akan dijadikan penambangan. Penebangan vegetasi/pohon-pohon tentunya akan berdampak buruk pada lingkungan sekitar. Contoh vegetasi atau pohon yang ditebang untuk bisa membuka lokasi penambangan terdapat pada gambar 4.9.

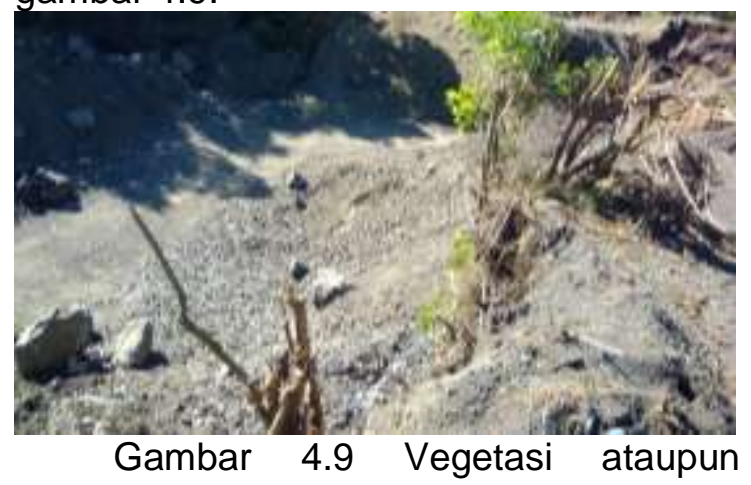

Pohon-Pohon Yang Hidup di Lokasi Penambangan (sumber: Dok. Alit, 2017)

Menghilangkan vegetasi ataupun pohon-pohon tersebut akan dapat berdampak buruk terhadap lingkungan sekitar, baik itu terhadap flora itu sendiri maupun terhadap fauna yang hidup di sekitarnya. Selain berdampak terhadap fauna dan flora juga berdampak terhadap keadaan tanah tersebut. Wilayah tersebut merupakan wilayah yang terjal, banyak terdapat tebing-tebing maupun jurangjurang yang berpotensi terjadinya longsor. Penambangan rakyat yang tidak memperhatikan aspek lingkungan akan menyebabkan terancamnya daerah sekitarnya dengan bahaya erosi dan tanah longsor karena hilangnya vegetasi penutup tanah (As'ad, 2005 ).

Tindakan yang merusak lingkungan dan dapat menimbulkan bencana terus dilakukan tiada lain karena kebutuhan akan pentingnya mineral pasir dan batu untuk pembangunan. Dengan pentingnya pasir dan batu membuat mineral ini memiliki nilai jual. Secara ekonomis penambangan pasir dan batu memiliki nilai jual yang bisa dikatakan menjanjikan, dimana nilai jual per 1 truk pasir dan batu dengan tinggi kurang lebih $80 \mathrm{~cm}$ sampai $90 \mathrm{~cm}$ seharga rata-rata Rp. 400.000 - RP. 600.000 harga yang berbeda-beda tersebut merupakan harga di lokasi penambangan. Perbedaan harga tersebut karena kualitas dari pasir itu sendiri. Jika kwalitas pasir tersebut baik, maka harga yang dipatok akan lebih mahal, begitu juga sebaliknya jika kualitas pesir buruk, maka harga yang dipatok sedikit lebih murah. Nilai jual pasir dan batu yang menjanjikan merupakan hal yang positif bagi pekerja tambang, seperti yang diketahui bersama bahwa pasir dan batu biasanya digunakan untuk kepentingan infrastruktur baik berupa jalan, jembatan, rumah dan lain sebagainya. Seperti penuturan sekretaris Desa Batur, Bapak Sujana mengatakan harga pasir dan batu yang menjanjikan membuat masyarakat sekitar yang memiliki mata pencaharian petani beralih mata pencaharian menjadi penambang pasir dan batu.

Selain harga yang menjanjikan pekerjaan penambang pasir dan batu membuat tertarik bagi masyarakat yaitu dibagian pemasarannya. Pemasaran pasir dan batu tersebut sangat mudah sekali. Hal tersebut karena pekerja tidak perlu sulit-sulit untuk menyiapkan alat transportasi (truk) maupun tidak perlu mengantar ke lokasi pembeli ataupun calon pembeli, karena truk dan pembeli ataupun calon pembeli yang langsung datang ke lokasi. Calon pembeli ataupun pembeli berasal dari berbagai kecamatan hingga sampai keluar Kabupaten Bangli, namun hanya meliputi Pulau Bali saja. Pemasaran pasir dan batu yang meliputi wilayah Bali dikarenakan persedian pasir 
dan batu di lokasi penambangan selalu tersedia. Selain persediaan pasir dan batu selalu tersedia, kualitas pasir dan batu yang baik dan cocok untuk kebutuhan masyarakat untuk bangunan seperti rumah, senderan tebing dan lain sebagainya.

\section{Dampak Aktivitas Penambangan Pasir dan batu Terhadap Kelestarian Geopark di Kaldera Gunung Batur.}

Dampak yang ditimbulkan dari aktivitas penambangan pasir dan batu yaitu berdampak pada kondisi $A B C$ (kondisi Abiotik, Kondisi Biotik, dan Kondisi Sosial Budaya/culture) yang berpengaruh terhadap kelestarian geopark di Kaldera Gunung Batur. Dalam KBBI melestarikan atau kelestarian yaitu menjadikan (membiarkan) tidak berubah atau membiarkan tetap seperti semula, sedangkan pelestarian merupakan perlindungan dari kemusnahan atau kerusakan, pengawetan dan konservasi. Berikut ketiga kondisi tersebut akan dibahas pada ulasan di bawah.

Dampak terhadap kondisi fisik yang diakibatkan berupa kerusakan lingkungan di Kaldera Gunung Batur. Hal tersebut disebabkan penimbunan bekas tambang sebagian besar responden menjawab kadang-kadang saja para pekerja melakukan penimbunan bekas tambang, namun dari 41 responden 11 responden selalu melakukan penimbunan lubang bekas tambang.

Penimbunan yang dilakukan pekerja tambang dikerjakan disela-sela kegiatan saat melakukan penggalian. Penimbunan yang dilakukan pekerja tambang tidak semerta-merta semua penambang menimbun menggunakan tanah. Hal tersebut dikarenakan sulitnya mencari tanah di areal penambangan. Para pekerja tambang menimbun bekas tambang menggunakan pasir yang tercampur dengan tanah, dimana jenis pasir ini tidak laku jika dijual. Lahan bekas kegiatan pertambangan menunggu pelaksanaan reklamasi pada tahap akhir penutupan tambang. Kalau lahan yang telah selesai digunakan secara bertahap direklamasi, maka lahan tersebut dapat menjadi lahan produktif (Nurdin, dkk, 2000).

Jika bekas lokasi penambangan tidak dilakukan penimbunan maupun perataan, maka dapat meninggalkan kubangan-kubangan/lubang-lubang besar di bekas lokasi penambangan pasir dan batu dan menghasilkan limbah bantak yang bertumpuk di berbagai lokasi. Bantak merupakan kerakal dan batu berukuran kecil sampai besar yang merupakan sisa kegiatan penambangan. Sebagian besar lokasi bekas galian pasir dan batu ditutup oleh tumpukan bantak yang tingginya mencapai beberapa meter. Pada gambar 4.10 merupakan contoh tumpukan Bantak di lokasi penelitian.

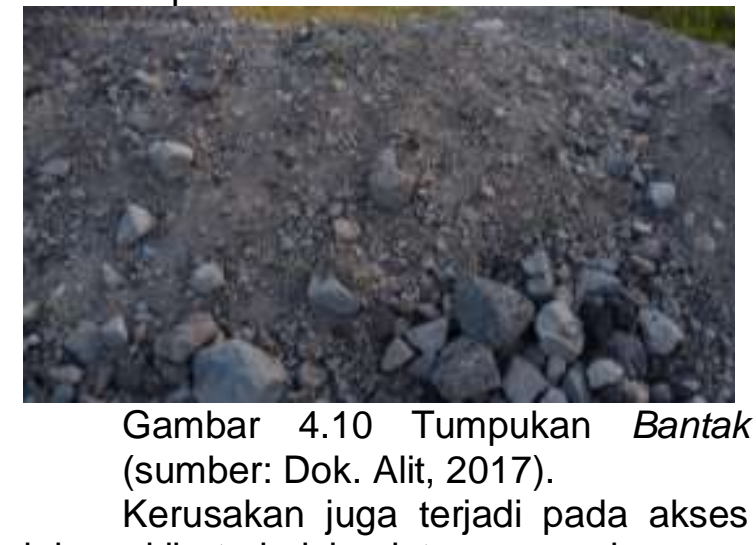
jalan akibat dari kegiatan penambangan. Kerusakan jalan yang paling terlihat jelas di jalur Culali Batur. Banyaknya truk-truk yang membawa pasir maupun batu yang melewati jalan tersebut semakin memperparah kerusakan jalan di lokasi tersebut. Jalur Culali Batur merupakan jalur truk pembawa pasir dan batu. Kerusakan jalan akibat penambangan pasir bukan hanya terjadi di lokasi ini saja melainkan hampir di semua lokasi penambangan pasir. Yudhistira dkk (2011), faktor fisik yang terjadi akibat adanya penambangan salah satunya tingginya lalu lintas kendaraan, sehingga membuat mudah rusaknya jalan.

Beda halnya mengenai keadaan udara. Walaupun ada aktivitas penambangan pasir dan batu udara yang terdapat di lokasi penambangan bisa dikatakan baik. Dari 41 responden yang diberikan kuesioner 11 responden menjawab keadaan udara baik-baik saja, sedangkan sisanya menjawab keadaan 
udara tidak berpengaruh. Selain tidak adanya pengaruh dengan keadaan udara juga tidak berpengaruh terhadap pertanian/perkebunan.

Walaupun penambang mengatakan keadaan udara baik-baik saja, tetapi dengan adanya kegiatan penggaliaan bahan tambang tentunya akan dapat merusak keadaan udara. Hal tersebut karena penambang menebang pohonpohon ataupun vegetasi yang dijadikan lokasi penambangan. Tentunya hal tersebut akan dapat mengurangi jumlah oksigen yang seharusnya. Selain terjadinya penebangan pohon pengangkutan material pasir disaat musim kemarau juga berdampak pada berhamburannya debu pasir ke udara. Walaupun hal tersebut belum berdampak, tetapi jika hal itu dilalukan dengan skala yang lebih besar lagi, maka tidak menutup kemungkinan terasa dampaknya. Berdasarkan PP No. 41 tahun 1999, untuk mendapatkan udara sesuai dengan tingkat kualitas yang diinginkan maka pengendalian pencemaran udara menjadi sangat penting untuk dilakukan.

Dampak terhadap kondisi biotik yang ditimbulkan akibat aktivitas penambangan yaitu pada flora (tumbuhan / vegetasi) dan fauna (hewan) yang ada disana. Terganggunya tersebut karena tumbuhan yang ada di atas lokasi/lahan penambangan harus ditebang terlebih dahulu agar pasir maupun batu dapat digali oleh pekerja tambang. Tentunya dengan penebangan tumbuhan akan juga berdampak pada fauna (hewan) yang hidup didalam vegetasi tersebut. Dampaknya tersebut sangat jelas sekali karena habitat dari hewan tersebut ditebang, sehingga terjadi ketidakseimbangan ekosistem. Jika hal tersebut terus terjadi, maka hewan maupun tumbuhan yang semestinya hidup di wilayah tersebut akan punah.

Selain hilangnya flora dan fauna yang ada di atas lokasi / lahan penambngan. Dampak lain juga terjadi pada fauna di sekitar lahan penambangan, dimana aktivitas dari manusia/penambang akan dapat mengusik keberadaan fauna yang hidup disana. Selain terusiknya keberadaan fauna yang berada di sekitar lahan penambngan, suara dari mesinmesin yang digunakan penambang juga dapat mengganggu fauna tersebut.

Selain dampak terhadap kondisi biotik penambangan pasir dan batu juga berdampak terhadap kondisi sosial, dimana dengan adanya aktivitas penambangan kesempatan untuk bekerja masyarakat sekitar lebih luas. Responden sendiri menjawab penambangan pasir dan batu memberi kesempatan untuk bekerja bagi mereka. Selain memberi kesempatan bekerja bagi penambang pasir dan batu juga memberi kesempatan masyarakat sekitar untuk berjualan. Hal tersebut dikarenakan adanya sopir truk yang biasanya sambil menunggu pasir ataupun batu yang dibeli selesai diangkut ke truk sopir biasanya belanja di warung-warung dekat lokasi penambangan yang berjualan makanan dan minuman. Hal yang sama juga didukung oleh hasil penelitian yang dilakukan oleh Yudhistira dkk (2011), menyatakan bahwa dampak sosial ekonomi yang terjadi dengan adanya kegiatan penambangan pasir yaitu jumlah pengangguran karena sebagian masyarakat bekerja menjadi tenaga kerja di penambangan pasir, baik sebagai pengawas, buruh tambang, penjual makanan dan minuman.

Mengenai indeks kemampuan lindung yang didapatkan, yaitu

$$
\begin{aligned}
I K L \text { wil } & =\frac{L K L}{0,3 x(L K L+L K B)} \times 100 \% \\
I K L \text { wil } & =\frac{2140,2}{0,3 x(2140,2+574,01)} \times 100 \% \\
I K L \text { wil } & =\frac{2140020}{814,263}
\end{aligned}
$$$$
\text { IKL wil }=29,5
$$

Berdasarkan hasil perhitungan, IKLwil yang didapat $=29,5$. Muta'ali (2012), suatu kawasan lindung berfungsi dengan optimal untuk melindungi kelestarian lingkungan hidup apabila IKLwil $>1$. Begitu juga sebaliknya, apabila IKLwil $<1$, dapat diartikan bahwa kemampuan kawasan lindung wilayah berfungsi kurang atau belum optimal. Dengan demikian dapat disimpulkan bahwa kelestarian Geopark di Kaldera Gunung Batur masih berfungsi dengan optimal kelestariannya. Hal tersebut 
dikarenakan penambang yang melakukan penggalian pasir dan batu di lahan milik sendiri atau di luar area konservasi/lindung.

\section{SIMPULAN}

Berdasarkan pemaparan hasil penelitian dan pembahasan yang telah disajikan di atas dapat dikemukakan beberapa kesimpulan sebagai berikut:

1. Penambangan pasir dan batu di Kaldera Gunung Batur memiliki intensitas penambangan yang tinggi yaitu sebesar $70,73 \%$ pekerja tambang bekerja setiap hari. Selain itensitas yang tinggi, alat yang digunakan penambang dominan menggunakan kedua jenis alat yaitu modern dan tradisional (sederhana). Sebesar 56,10\% penambang menggunakan alat modern dan tradisional. Penggunaan kedua alat ini secara bersamaan bertujuan mempercepat pekerjaan dengan hasil galian yang lebih banyak. Tentunya dalam kegiatan ini agar dapat difungsikan alat modern dan tradisional memerlukan lahan (lokasi) untuk dapat digali. Berdasarkan hasil hasil survey di lapangan $77,78 \%$ lahan milik sendiri dan $22,22 \%$ lahan orang lain (menyewa).

2. Adapun jumlah pasir maupun batu yang digali setiap harinya oleh penambang rata-rata 1,5 truk. Penambang menggali pasir dan batu menggunakan teknik penambangan terbuka, yaitu dengan cara menghilangkan vegetasi / pohon-pohon yang hidup diatas lahan (lokasi) penambangan. Tentunya dengan hilangnya vegetasi / pohon-pohon dapat merusak lingkungan sekitar dan dapat menimbulkan risiko bencana, seperti longsor. Tindakan yang merusak tersebut tetap dilakukan karena kebutuhan akan mineral pasir dan batu serta minera yang memiliki nilai jual yang dapat memenuhi kebutuhan hidup sehari-hari. Secara ekonomis nilai jual pasir dan batu per truk seharaga $\mathrm{Rp}$. 400.000. Selain harga yang menjanjikan, penambang tidak perlu bingung untuk menjuan maupun memasarkan hasil tambangnya. Hal tersebut dikarenakan pembeli yang langsung datang ke lokasi penambangan.
3. Akibat adanya aktivitas penambangan menimbulkan dampak terhadap kondisi abiotik, kondisi biotik, dan kondisi sosial budaya. Dampak yang paling jelas terlihat yaitu pada kondisi fisik, yaitu banyaknya lubang-lubang bekas tambang, serta sisa-sisa pasir dan batu yang tidak laku terjual. Hal tersebut dikarenakan penimbunan bekas tambang hanya kadang-kadang saja dilakukan penimbunan. Kerusakan fisik lain juga terjadi pada akses jalan. Truk yang digunakan sebagai alat transportasi kegiatan penambangan membuat jalan tersebut menjadi cepat rusak. Hal tersebut dikarenakan truk beserta muatan pasir maupun batu memiliki berat 12 ton lebih. Sedangkan mengenai keadaan udara berdasarkan kuesioner pekerja tambang memberikan jawaban keadaan udara yang baik-baik saja.

Dampak biotik yang ditimbulkan akibat dari aktivitas penambngan yaitu terjadi pada pada flora dan fauna. Hal tersebut dikarenakan tempat hidup flora dan fauna sudah berganti menjadi lokasi / lahan penambangan. Hal lain juga terjadi pada fauna yang hidup di sekitar lahan penambangan. Suara mesin penggali pasir dan batu dapat mengusik keberadaan fauna sekitarnya. Selain dampak kondisi biotik, penambanagan pasir dan batu juga berdampak pada kondisi sosial. Adanya aktivitas penambangan memberi kesempatan kerja masyarakat sekitar lebih luas. Selain memberi kesempatan kerja di penambangan, masyarakat juga bisa menjadi pedagang makanan maupun minuman. Sedangakan kelestarian dari geopark masih dapat dikatakan lestari, karena penambang melakukan aktivitas penggalian di luar kawasan konservasi/lindung.

\section{SARAN}

Berdasarkan pada hasil yang diperoleh pada penelitian ini, dapat dikemukakan beberapa saran, yaitu sebagai berikut:

1. Masyarakat di Kaldera Gunung Batur hendaknya sejak dini melakukan penimbunan lubang bekas tambang, 
sehingga jika musim hujan lahan bekas lokasi tambang tidak rawan longsor.

2. Masyarakat di Kaldera Gunung Batur hendaknya lebih memperhatikan lingkungan, dengan cara menanami vegetasi yang mati akibat dari kegiatan penambangan pasir dan batu.

Pemerintah Kabupaten Bangli hendaknya terus memperhatikan dan menjaga kelestarian lingkungan di Kaldera Gunung Batur, sehingga kerusakan yang diakibatkan dari aktivitas penambangan bisa diminimalisir. Salain itu, perlu adanya pengawasan terhadap aktivitas yang dilakukan penambang pasir dan batu, agar dalam kegiatan penambangannya lebih mengedepankan lingkungan sekitar.

\section{DAFTAR PUSTAKA}

Arikunto, S. 2010. Prosedur Penelitian Suatu Pendekatan Praktek. Jakarta: Rineka Cipta.

As'ad. 2005. Pengelolaan Lingkungan pada penambangan Rakyat (Studi Kasus Penambangan Intan Rakyat di Kecamatan Cempaka Kota Banjarbaru Propensi Kalimantan Selatan). Kalimantan: mill undip.

Dyahwanti, Inarni Nur. 2007. Kajian Dampak Lingkungan Kegiatan Penambangan Pasir Pada Daerah Sabuk Hijau Gunung Sumbing Di Kabupaten Temanggung. Semarang: Universitas Diponegoro.

Kaliti. 1983. Sumber Daya Alam untuk Pembangunan Nasional. Jakarta: Ghalia Indonesia.

Kartodiharjo. 2005. Di Bawah Satu Payung Pengelolaan Sumber Daya Alam. Jakarta: Suara Bebas.

Lutfi M.A. 2014. Perencanaan Pengembangan Wilayah Berbasis Pengukuran Risiko Bencana. Yogyakarta:BPFG Universitas Gajah Mada.

Muzambiq., Abduh, M., Sobirin., Nainggolan, Rolas. 2016. informasi geologi lingkungan berbasis partisipasi masyarakatsebagai kawasan geowisata danau toba di kabupaten samosir. Jurnal Penelitian Pendidikan Sosial dan Humaniora. Volume 1, Nomor 1 (hlm 22-28).

Nurdin, A., Wiriosudarmo,R., Gautama, R.S., Arif, I., 2000. Agenda 21 Sektoral Agenda Pertambangan untuk Pengembangan Kualitas Hidup Secara Berkelanjutan. Jakarta: Kantor Menteri Negara Lingkungan Hidup.

Nurul In ., Sriartha, I Putu ., Citra, I Putu Ananda. 2016. Dampak Aktivitas Pertambangan Pasir dan batu Terhadap Keberlanjutan Sumber Daya Pertanian di Kecamatan Aikmel. Jurnal Media Komonikasi Geografi. Volume 17, Nomor 1 (hlm 39-46).

PP No. 41 Tahun 1999. Tentang Pengendalian pencemaran Udara. Jakarta, Kementrian Lingkungan Hidup.

Sukandarrumidi. 1997. Batu Bahan Galian Industri. Yogyakarta: Universitas Gajah Mada Press.

Subowo. 2011. Penambangan Sistem Terbuka Ramah Lingkungan Dan Upaya Reklamasi Pasca Tambang Untuk Memperbaiki Kualitas Sumber daya Lahan Dan Hayati Tanah. Bogor : Institut Pertanian Bogor.

Usman, Husaini dan Purnomo setiady Akbar. 2011. Metode Penelitian Sosial. Jakarta: Bumi Aksara.

Voaindonesia. $2015 . \quad$ "Kegiatan Penambangan Ancam Kawasan Gunung Batur di Bali". Tersedia pada

http://www.voaindonesia.com/a/kegi atan-penambangan-ancamkawasan-gunung-batur-dibali/1712709.html. Html (diakses tanggal 28 September 2016).

Yudhistira., Hidayat, Wahyu Krisna., Hadiyarto, Agus. 2011. Kajian Dampak Kerusakan Akibat Kegiatan Penambangan Pasir di Desa Keningar Daerah Kawasan Gunung Merapi. Jurnal Ilmu Lingkungan. Volume 9 Nomor 2. (hlm 76-84). 